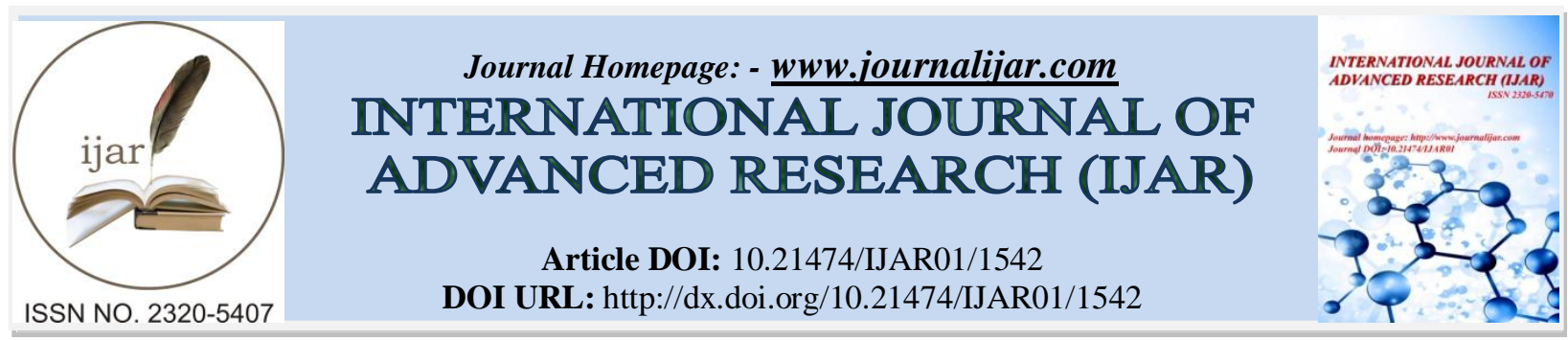

RESEARCH ARTICLE

\title{
PREPARATION AND CHARACTERIZATION OF NANO Fe(III) OXIDE BY THE THERMAL DECOMPOSITION OF Fe(III) CHELATES.
}

S Mini" and V Sadasivan.

Department of Chemistry, University College, Trivandrum, 695034 Kerala, India.

\section{Manuscript Info}

Manuscript History

Received: 15 July 2016

Final Accepted: 19 August 2016

Published: September 2016

Key words:-

Fe(III) oxide, Thermal decomposition,

SEM, TEM

\section{Abstract}

Four Fe(III) chelates of different ligands (azodyes and Schiff bases) were prepared and characterized by different physico-chemical methods. The pyrolytic temperatures of these chelates were found out by thermo gravimetric analysis. These Fe(III) chelates were converted to nano sized $\mathrm{Fe}(\mathrm{III})$ oxides by thermal decomposition method. The nano $\mathrm{Fe}$ (III) oxides were characterized by FTIR, and XRD techniques, confirmed the formation of $\alpha-\mathrm{Fe}_{2} \mathrm{O}_{3}$ and $\gamma-\mathrm{Fe}_{2} \mathrm{O}_{3}$. Analysis of SEM and TEM was carried out to study the morphology and particle size. The results showed that the particles obtained from the thermal analysis of the iron chelates were nano sized $\alpha$ and $\gamma$ variety of $\mathrm{Fe}_{2} \mathrm{O}_{3}$. It is once again confirmed from the VSM measurements.

Copy Right, IJAR, 2016,. All rights reserved.

\section{Introduction:-}

Iron oxide exists in various forms, among which hematite $\left(\alpha-\mathrm{Fe}_{2} \mathrm{O}_{3}\right)$ and maghemite $\left(\gamma-\mathrm{Fe}_{2} \mathrm{O}_{3}\right)$ are of great importance in industry and technology (Huo, et al., 2000). The $\beta-\mathrm{Fe}_{2} \mathrm{O}_{3}$ form is very rarely found. $\alpha-\mathrm{Fe}_{2} \mathrm{O}_{3}$ has a hexagonally close packed array with $\mathrm{Fe}^{3+}$ ions occupying the octahedral interstices. The $\gamma-\mathrm{Fe}_{2} \mathrm{O}_{3}$ may be regarded as a cubic close packed of oxide ions with the $\mathrm{Fe}^{3+}$ ions distributed randomly over both the octahedral and tetrahedral interstices (Cotton F. A. \& Wilkinson G., 1988). Maghemite has a lot of applications, such as recording memory devices, magnetic resonance imaging, drug delivery etc (Daou, et al., 2010). Hematite has been extensively used as photo-anode for photo assisted electrolysis of water because of its high resistance to corrosion, It is also used as ferrofluids, shock absorbers, heat transfer fluids etc (Wang and Meng, 2001; Espì n, et al., 2004). These materials in the nano size range show more enhanced properties than that itself in the micron size. Thus iron oxide in the nano size range became an important material for many industrial, scientific and technological applications. In recent years so many works have been done in this, especially in the synthesis of nano sized $\mathrm{Fe}_{2} \mathrm{O}_{3}$. Its non toxicity, low cost and relatively good stability are definitely attractive features for application. Nano sized $\alpha-\mathrm{Fe}_{2} \mathrm{O}_{3}$ shows unusual magnetic behaviour depending on the size and shape of the $\alpha-\mathrm{Fe}_{2} \mathrm{O}_{3}$ particles. $\alpha-\mathrm{Fe}_{2} \mathrm{O}_{3}$ has got much attraction because of effect of size and shape on the corresponding properties (Hyon Gil Cha, et al., 2009).

A number of experimental techniques have been developed to produce maghemite and hematite with controlled size shape and size dispersion (Daou, et al., 2010). Thermal decomposition (Murray, C.B., et al., 1993), micro emulsion (Langevin, D., 1992) and hydrothermal methods (Daou, T.J., 2006) etc are few of them. The physical and chemical properties of nano sized particles do not depend on the atom and the bulk counterparts. (Sohn, B.H., et al., 1997). For biological and biomedical applications, magnetic iron oxide nanoparticles are chosen because of their superparamagnetic properties. In general, to be most effective, the nanoparticles must have high magnetization

Corresponding Author:- S Mini.

Address:- Department of Chemistry, University College, Trivandrum, 695034 Kerala, India. 
values. To be nontoxic and biocompatible, they must be small and have a narrow size distribution (Benyettou, F, et al., 2012 ; Taranta, M., et al., 2011).

In view of the importance of nano maghemite and hematite, the present investigation is undertaken to synthesize nano iron oxide by thermal decomposition method and they are characterized by various analytical methods and surface morphological study. Thermal decomposition studies of iron(III) complex have been investigated by several workers (Ananda Kumar Sharma, 1986; Lanjewar, R.B., et al., 1996). Thermal decomposition studies of iron(III) complexes by thermo gravimetric analysis shows that the end product is $\alpha-\mathrm{Fe}_{2} \mathrm{O}_{3}$. In a particular case, $\gamma-\mathrm{Fe}_{2} \mathrm{O}_{3}$ is formed as the intermediate product but it has converted to $\alpha-\mathrm{Fe}_{2} \mathrm{O}_{3}$ finally. They observed that the thermal decomposition follows first order kinetics and an intramolecular rearrangement may be taking place during decomposition (Sonal Singhal, et al., 2007).

\section{Experimental:-}

Materials and methods:-

All the chemicals used for the syntheses were high purity grade and were purchased from their manufactures. The newly prepared ligands and Fe(III) chelates were characterised by various physico-chemical methods. TG and DTG analysis of four $\mathrm{Fe}(\mathrm{III})$ complexes were carried out on a simultaneous TG/DTG analyser. The TG curves were recorded from ambient temperature to $1000^{\circ} \mathrm{C}$ in an atmosphere of $\mathrm{N}_{2}$ at a linear heating rate of $10^{\circ} \mathrm{C} /$ minute. Surface studies have been carried out by using FEG-SEM and TEM analyses. SEM analysis has been done on FEGSEM JSM-7600F at IIT, SAIF, IIT Mumbai. TEM analysis has been done on Philips CM 200/20-200KV TEM at IIT, Mumbai. The IR spectrum of the Fe(III) oxides obtained from all the four complexes were recorded on a Shimadzu FTIR spectrometer by $\mathrm{KBr}$ disc method. The powder XRD spectrum of iron oxide sample obtained from $\left[\mathrm{Fe}(\mathrm{RABP}) \mathrm{Cl}_{2}\left(\mathrm{H}_{2} \mathrm{O}\right)_{2}\right]$ was done on Philips X-ray diffractometer (PW1710)using $\mathrm{Cu} \mathrm{K} \alpha$ radiation with $\lambda=1.5405$ $\mathrm{A}^{\mathrm{o}}$. VSM measurements of $\mathrm{Fe}$ oxide obtained from the pyrolysis of $\left[\mathrm{Fe}(\mathrm{RABP}) \mathrm{Cl}_{2}\left(\mathrm{H}_{2} \mathrm{O}\right)_{2}\right]$ complex was done on Lakeshore VSM 7410 at SAIF, IIT Chennai.

\section{Preparation of the ligands and complexes:-}

Four Fe(III) chelates were prepared from the azodyes RABP, ANSN and Schiff base FABP and FAHP. The preparation of Fe(III) chelates of RABP, ANSN, FAHP and FABP are reported. (Mini S, et al., 2013, Mini S, et al., 2014 Mini S, et al.,2015). RABP is [2-chloro-5-(2,4-dihydroxyphenylazo)phenyl]phenylmethanone which is prepared by diazotizing 2-amino-5-chloro benzophenone and coupling with resorcinol. ANSN is [3-hydroxy-4-(1hydroxy naphthalen-2-ylazo)naphthalene -1-sulfonic acid, prepared by diaotising 1-amino-2-naphthol-4-sulfonic acid coupling with 2-naphthol). FAHP is [ $\{2$-[furan-2-yl methyleneamino]pyridine-3-ol $\}]$ is prepared by condensing 2-amino-3-hydroxy pyridine with furfuraldehyde and FABP \{5-chloro-2-(furan-2-yl methylamino)phenyl)phenylmethanone, by condensing 2-amino-5-chlorobenzophenone with furfuraldehyde.

The Fe(III) chelates were prepared by refluxing $\mathrm{FeCl}_{3} \cdot 2 \mathrm{H}_{2} \mathrm{O}$ with the above mentioned ligands for about $4-5$ hours. The precipitates were filtered washed with cold methanol and dried over anhydrous $\mathrm{CaCl}_{2}$. The prepared complexes were characterized by various physico- chemical methods such as estimation of metal ions and anions, elemental analysis, conductance and magnetic susceptibility measurements and spectral techniques like FTIR, UV-Vis, Mössbauer and mass. From the result obtained the complexes are formulated as

$\left[\mathrm{Fe}(\mathrm{RABP}) \mathrm{Cl}_{2}\left(\mathrm{H}_{2} \mathrm{O}\right)_{2}\right],\left[\mathrm{Fe}(\mathrm{ANSN}) \mathrm{Cl}\left(\mathrm{H}_{2} \mathrm{O}\right)_{2}\right],\left[\mathrm{Fe}(\mathrm{FABP})_{2} \mathrm{Cl}_{2}\right] \mathrm{Cl},\left[\mathrm{Fe}(\mathrm{FAHP}) \mathrm{Cl}_{2}\left(\mathrm{H}_{2} \mathrm{O}\right)_{2}\right]$.

\section{Preparation of $\mathrm{Fe}_{2} \mathrm{O}_{3}$ powder:-}

The thermo gravimetric analyses of all the complexes were carried out in a simultaneous TG/DTA analyser. From the thermograph obtained for each of the sample the temperature at which the ligand completely leaves the material was marked. That particular temperature was different for different samples. A weighed amount of each of the complexes was subjected to controlled heat treatment in a pre-programmed muffle furnace up to the pyrolytic temperature. After obtaining the required furnace temperature the material was allowed to cool gradually. The product obtained was analysed for the metal percentage and for the final material. The final product obtained was found to be $\mathrm{Fe}_{2} \mathrm{O}_{3}$ in all the samples. 


\section{Results and Discussion:-}

Thermal analysis:-

All the metal complexes show a general trend in thermal decomposition. The hydrated complexes lose molecules of hydration first; followed by decomposition of ligand molecules in subsequent step. From the TG curves the pyrolysed temperatures (the temperature at which the ligand leaves from the complex molecule) of the four complexes were determined. The pyrolytic temperature is specific for each complex. The $\left[\mathrm{Fe}(\mathrm{RABP}) \mathrm{Cl}_{2}\left(\mathrm{H}_{2} \mathrm{O}\right)_{2}\right]$ complex shows the pyrolytic temperature at $610^{\circ} \mathrm{C}$, for $\left[\mathrm{Fe}(\mathrm{ANSN}) \mathrm{Cl}\left(\mathrm{H}_{2} \mathrm{O}\right)_{2}\right]$ it is at $790^{\circ} \mathrm{C},\left[\mathrm{Fe}(\mathrm{FABP})_{2} \mathrm{Cl} l_{2}\right] \mathrm{Cl}$ shows the pyrolytic temperature at $730^{\circ} \mathrm{C}$ and $\left[\mathrm{Fe}(\mathrm{FAHP}) \mathrm{Cl}_{2}\left(\mathrm{H}_{2} \mathrm{O}\right)_{2}\right]$ shows at $490^{\circ} \mathrm{C}$.

\section{IR spectra of $\mathrm{Fe}(\mathrm{III})$ oxide residues:-}

IR spectral analysis was employed to confirm the transformation of $\mathrm{Fe}$ (III) complexes to $\mathrm{Fe}_{2} \mathrm{O}_{3}$ or $\mathrm{Fe}_{3} \mathrm{O}_{4}$ during the thermal treatments. In order to clarify the difference of IR spectra between $\mathrm{Fe}_{2} \mathrm{O}_{3}$ and $\mathrm{Fe}_{3} \mathrm{O}_{4}$, the magnified spectrum of samples were analyzed. The absorption in the range $400-750 \mathrm{~cm}^{-1}$ is characteristic for $\mathrm{Fe}-\mathrm{O}$ vibration mode of hematite (Stuart, B.H., 2004; Battisha, J.K., et al., 2006). In the IR spectrum of residue obtained from [Fe( $\left.\mathrm{FAHP}) \mathrm{Cl}_{2}\left(\mathrm{H}_{2} \mathrm{O}\right)_{2}\right]$ shows three broad peaks respectively at $555 \mathrm{~cm}^{-1}, 478 \mathrm{~cm}^{-1}$ and $466 \mathrm{~cm}^{-1}$ may correspond to $\mathrm{Fe}-\mathrm{O}$ stretching and bending vibration mode of $\gamma-\mathrm{Fe}_{2} \mathrm{O}_{3}$ (Kim, I.T., et al., 2010). The absorption spectrrum of the residue of [Fe(RABP) $\mathrm{Cl}_{2}\left(\mathrm{H}_{2} \mathrm{O}\right)_{2}$ ] exhibits peaks at 536 and $447 \mathrm{~cm}^{-1}$ are assigned to $\mathrm{Fe}-\mathrm{O}$ stretching and bending vibration mode of $\alpha-\mathrm{Fe}_{2} \mathrm{O}_{3}$ respectively (Zhao, et al., 2007). The spectrum of residue obtained from $\left[\mathrm{Fe}(\mathrm{FABP})_{2} \mathrm{Cl}_{2}\right] \mathrm{Cl}$ shows two broad peaks at $545 \mathrm{~cm}^{-1}$ and $474 \mathrm{~cm}^{-1}$ may due to $\gamma-\mathrm{Fe}_{2} \mathrm{O}_{3}$ and the IR spectra of the residue from [Fe(ANSN)Cl( $\left.\mathrm{H}_{2} \mathrm{O}\right)_{2}$ ] shows three broad peaks at 542, 478 and $459 \mathrm{~cm}^{-1}$ which also corresponds to $\gamma-\mathrm{Fe}_{2} \mathrm{O}_{3}$. From the IR spectral evidences we confirmed that the residue obtained is $\mathrm{Fe}_{2} \mathrm{O}_{3}$ in all the cases. $\alpha-\mathrm{Fe}_{2} \mathrm{O}_{3}$ shows two or three peaks which is related with its structure and size. $\gamma-\mathrm{Fe}_{2} \mathrm{O}_{3}$ also exhibits three peaks between $500-700 \mathrm{~cm}^{-1}$ which is different from $\mathrm{Fe}_{3} \mathrm{O}_{4}$ (Ning Du, et al., 2010). IR spectra of the $\mathrm{Fe}_{2} \mathrm{O}_{3}$ are shown in fig: 1-4.

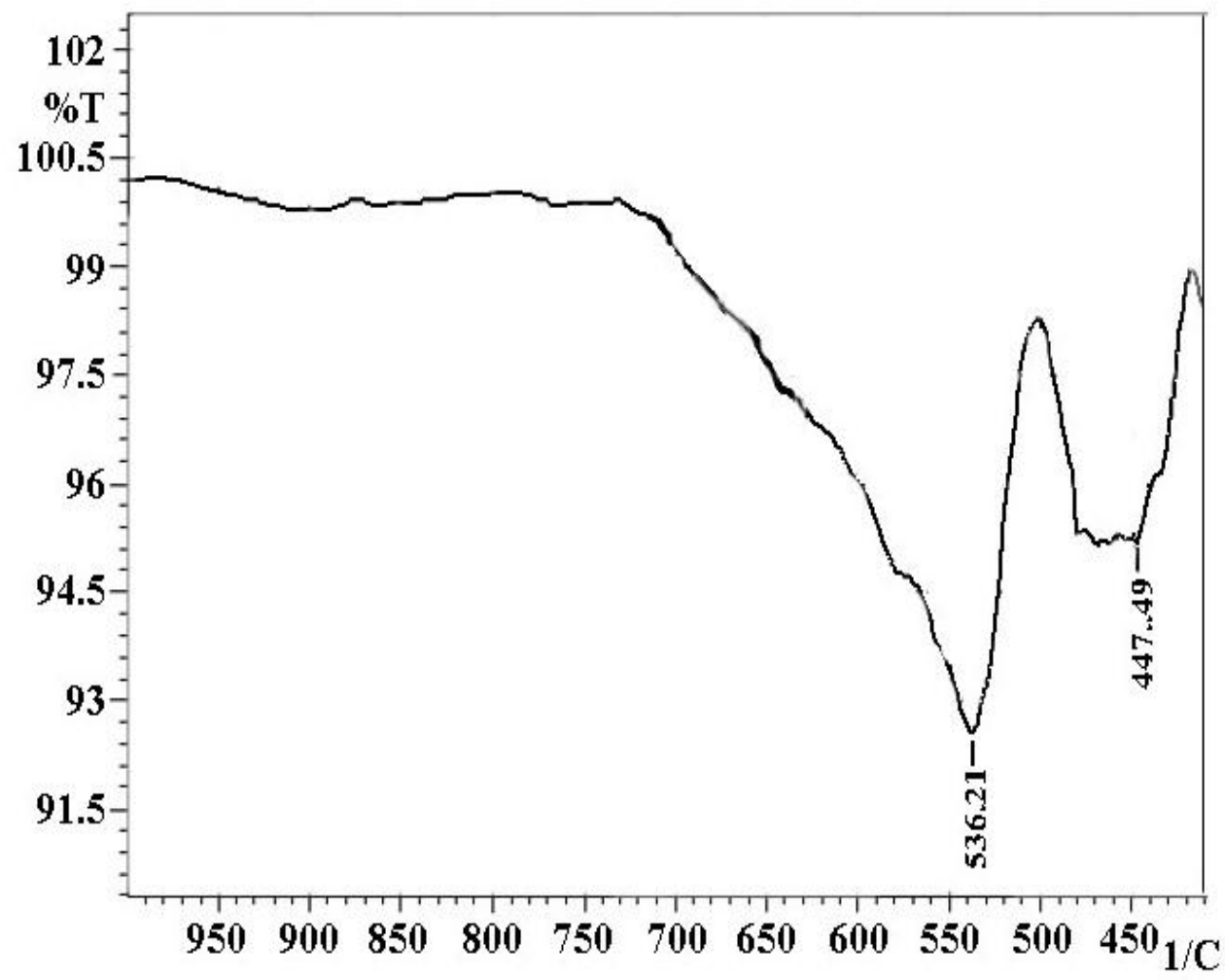

Fig 1:- IR spectrum of $\mathrm{Fe}_{2} \mathrm{O}_{3}$ obtained from $\left[\mathrm{Fe}(\mathrm{RABP}) \mathrm{Cl}_{2}\left(\mathrm{H}_{2} \mathrm{O}\right)_{2}\right]$ 


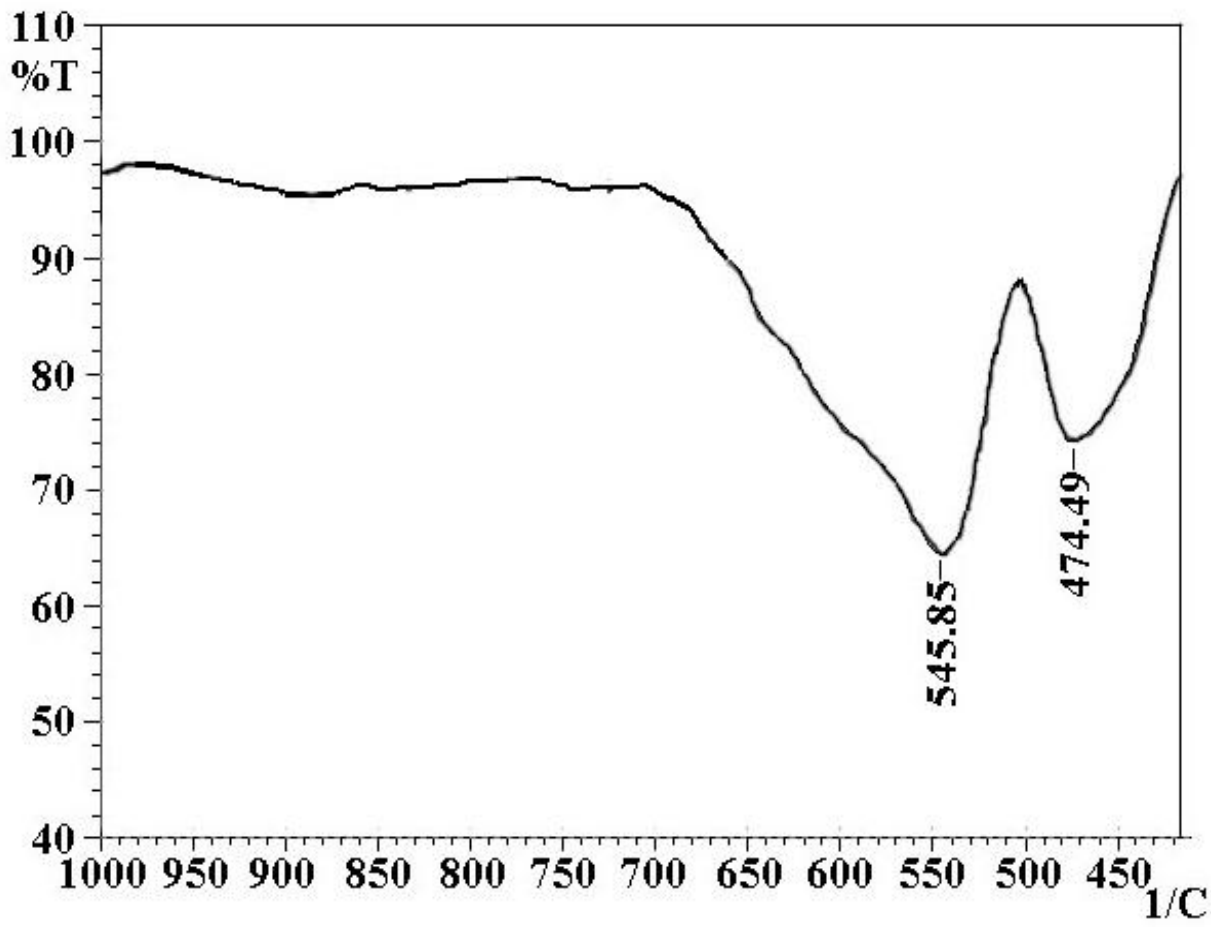

Fig 2:- IR spectrum of $\mathrm{Fe}_{2} \mathrm{O}_{3}$ obtained from $\left[\mathrm{Fe}(\mathrm{FABP})_{2} \mathrm{Cl}_{2}\right] \mathrm{Cl}$.

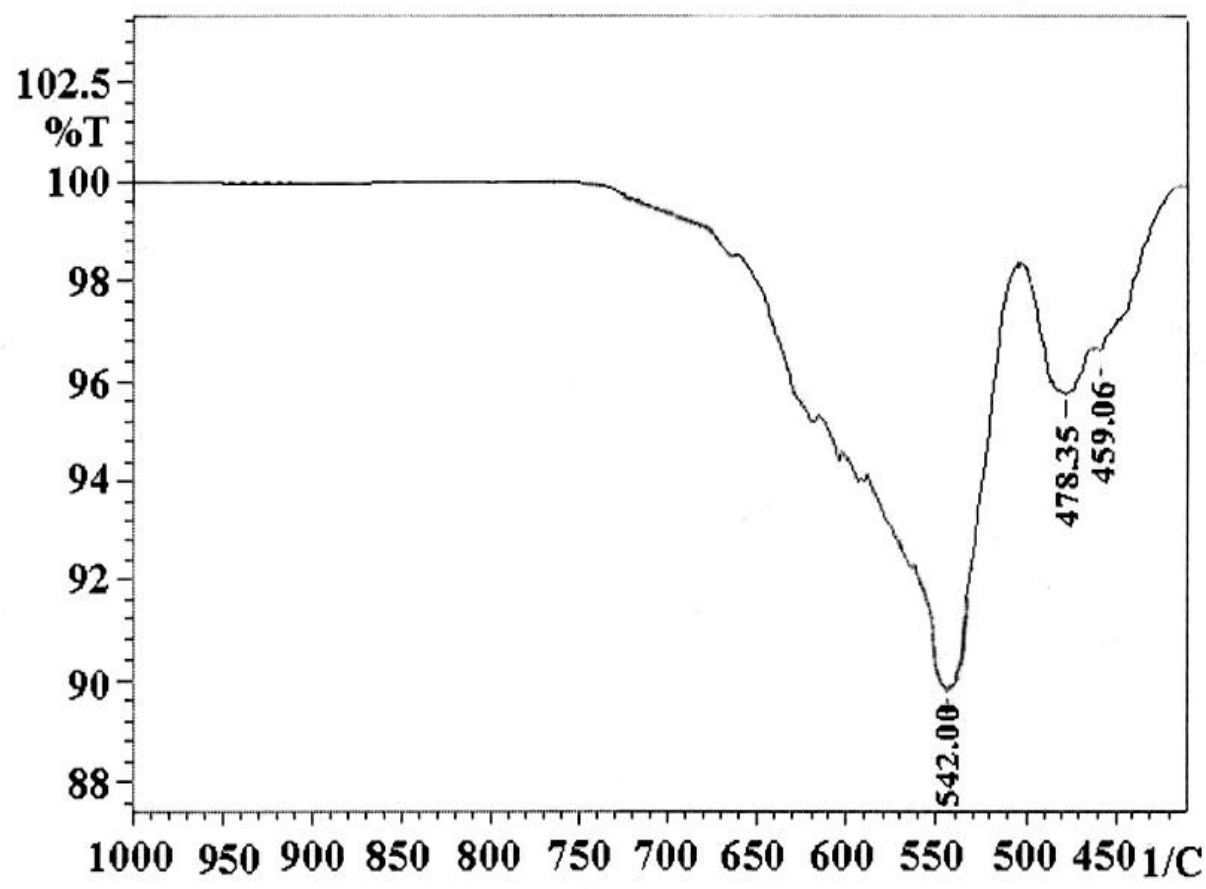

Fig 3:- IR spectrum of $\mathrm{Fe}_{2} \mathrm{O}_{3}$ obtained from $\left[\mathrm{Fe}(\mathrm{ANSN}) \mathrm{Cl}\left(\mathrm{H}_{2} \mathrm{O}\right)_{2}\right]$ 


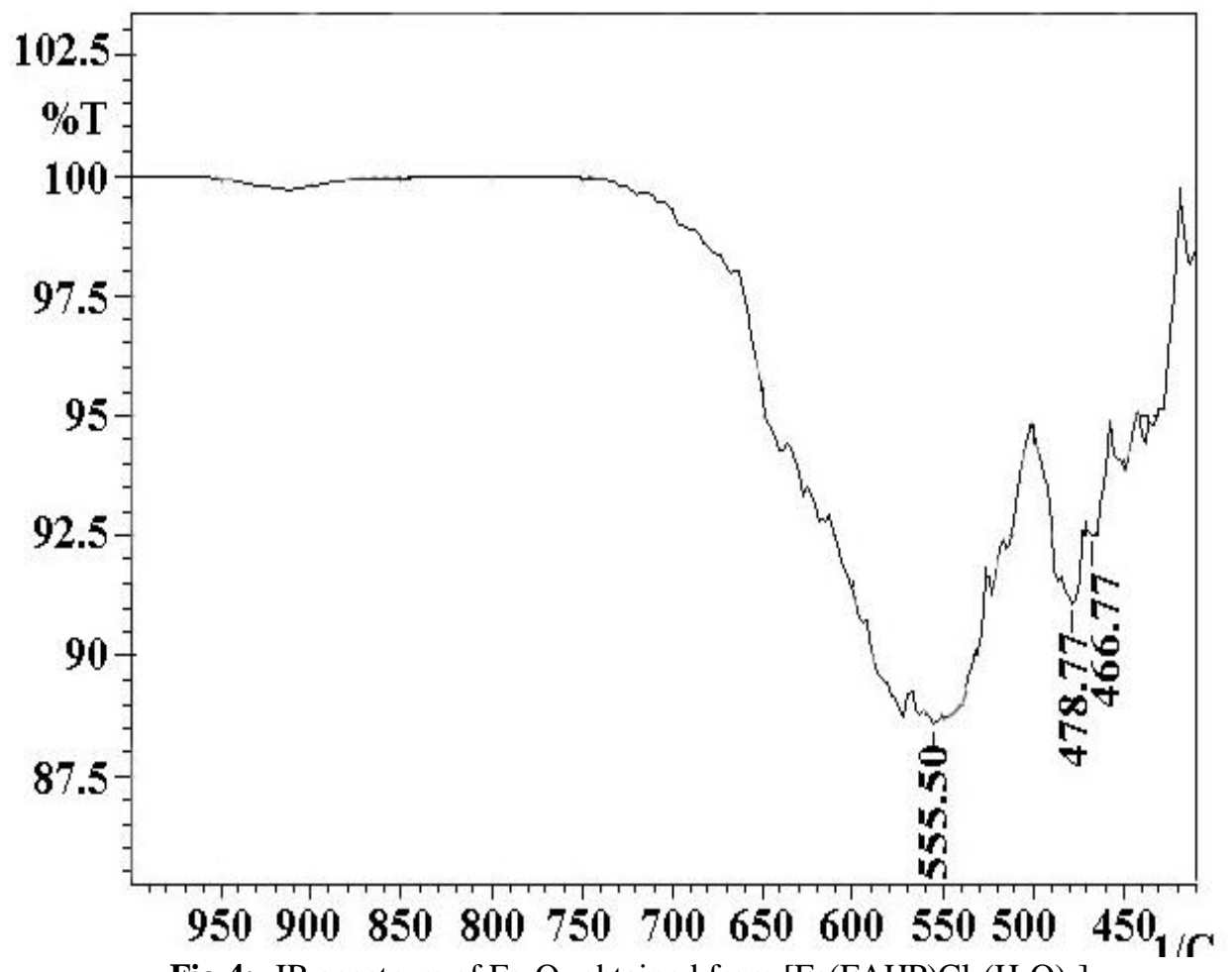

Fig 4:- IR spectrum of $\mathrm{Fe}_{2} \mathrm{O}_{3}$ obtained from $\left[\mathrm{Fe}(\mathrm{FAHP}) \mathrm{Cl}_{2}\left(\mathrm{H}_{2} \mathrm{O}\right)_{2}\right]$

FEG-SEM analysis of $\mathrm{Fe}_{2} \mathrm{O}_{3}$ :-

The SEM micrographs of the decomposition residue obtained by heating the complexes at its pyrolysed temperatures were analysed. The SEM micrograph of the $\mathrm{Fe}_{2} \mathrm{O}_{3}$ residue obtained after heating the complex [Fe(RABP) $\mathrm{Cl}_{2}\left(\mathrm{H}_{2} \mathrm{O}\right)_{2}$ ] at $610^{\circ} \mathrm{C}$ (its ligand leaving temperature) for about 20 minutes shows that there is less agglomeration of the particles. The particles show size approximately $1000 \mathrm{~nm}$. The particles appeared as flakes. So many voids are seen at the surface. SEM images are shown in fig: $5 \mathrm{a} \& 5 \mathrm{~b}$.

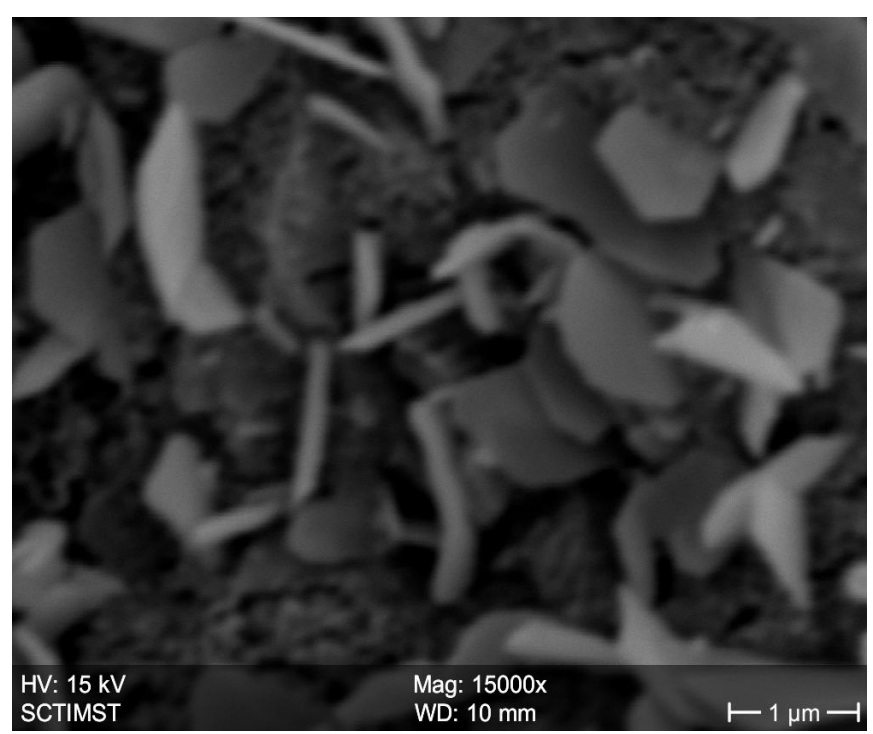

Fig 5a:- 


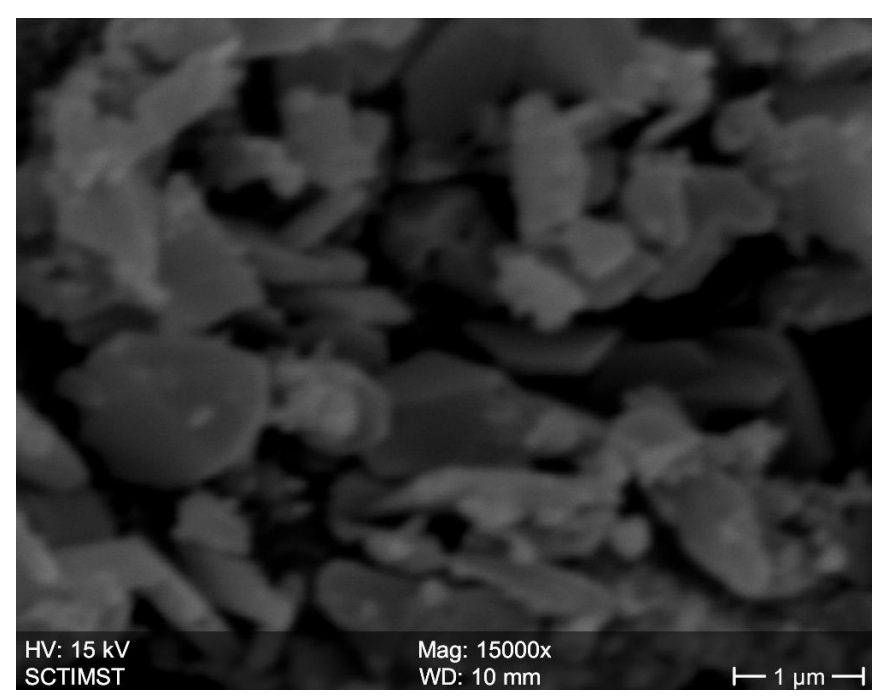

Fig 5b:- $\mathrm{SEM}$ images of $\mathrm{Fe}_{2} \mathrm{O}_{3}$ obtained from [ $\mathrm{Fe}(\mathrm{RABP}) \mathrm{Cl}_{2}\left(\mathrm{H}_{2} \mathrm{O}\right)_{2}$

The SEM micrograph of the decomposition product of the complex $\left[\mathrm{Fe}(\mathrm{ANSN}) \mathrm{Cl}\left(\mathrm{H}_{2} \mathrm{O}\right)_{2}\right]$ heated at $790^{\circ} \mathrm{C}$ shows spherically shaped particles aggregated in the flakes like structures which give a layer like appearance, voids are seen. The particles are in the size range of $48 \mathrm{~nm}$ to $182 \mathrm{~nm}$. Images are shown in fig: $6 \mathrm{a} \& 6 \mathrm{~b}$.

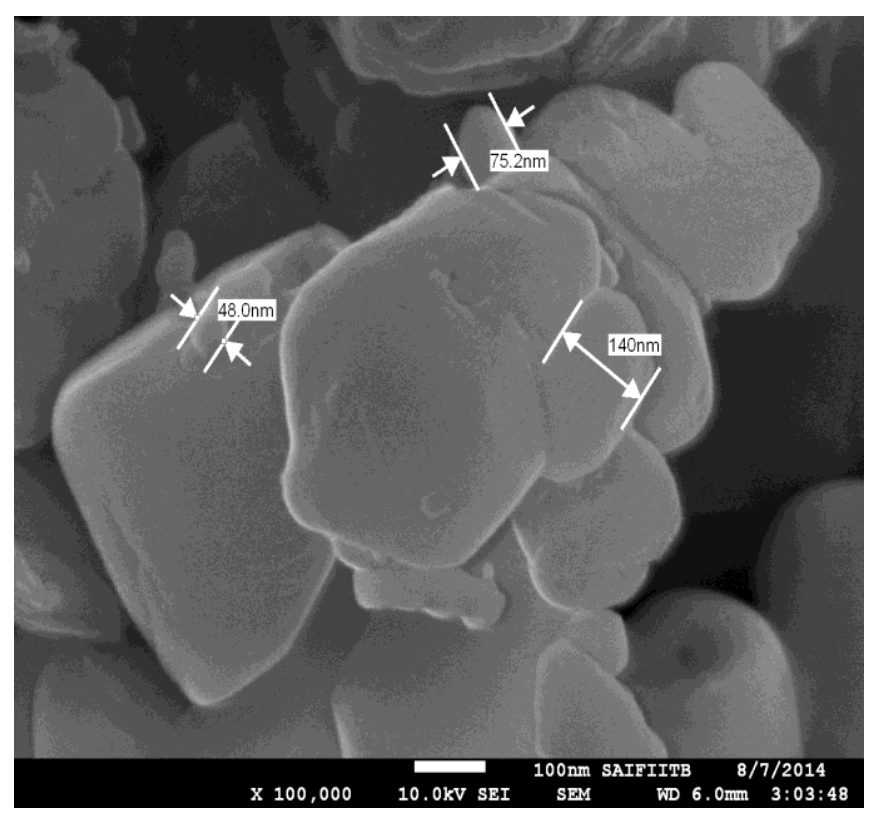

Fig 6a:- 


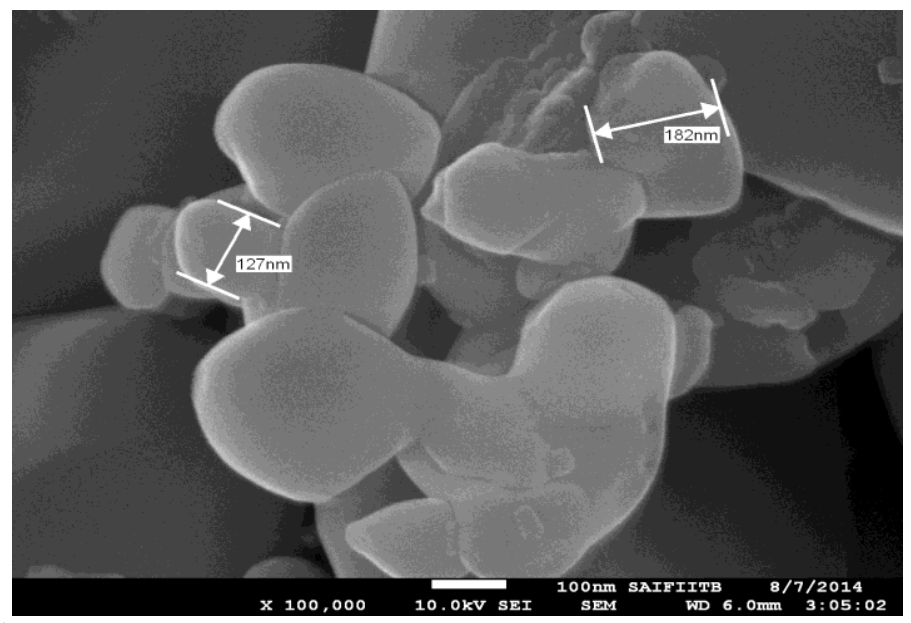

Fig 6 b:- SEM images of $\mathrm{Fe}_{2} \mathrm{O}_{3}$ obtained from [Fe(ANSN)Cl( $\left.\left(\mathrm{H}_{2} \mathrm{O}\right)_{2}\right]$

The SEM micrograph of the $\mathrm{Fe}_{2} \mathrm{O}_{3}$ residue obtained by heating the complex $\left[\mathrm{Fe}(\mathrm{FABP})_{2} \mathrm{Cl}_{2}\right] \mathrm{Cl}$ at $730^{\circ} \mathrm{C}$ for 30 minutes shows orderly arranged spherical shaped particles within the size range of $260 \mathrm{~nm}$ to $490 \mathrm{~nm}$. Aggregate particles are also seen in some places. SEM images are shown in fig:7a \&7b.

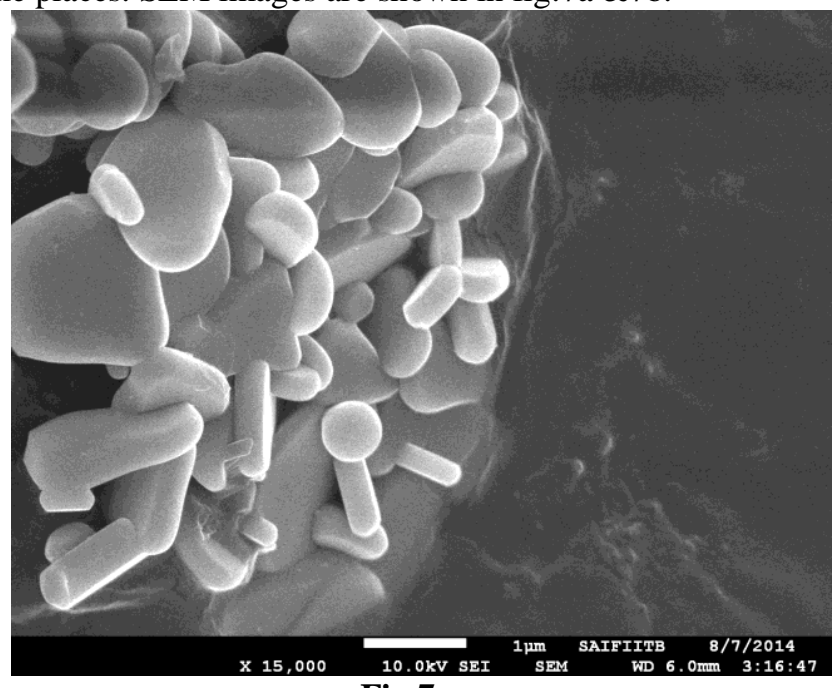

Fig 7a:-

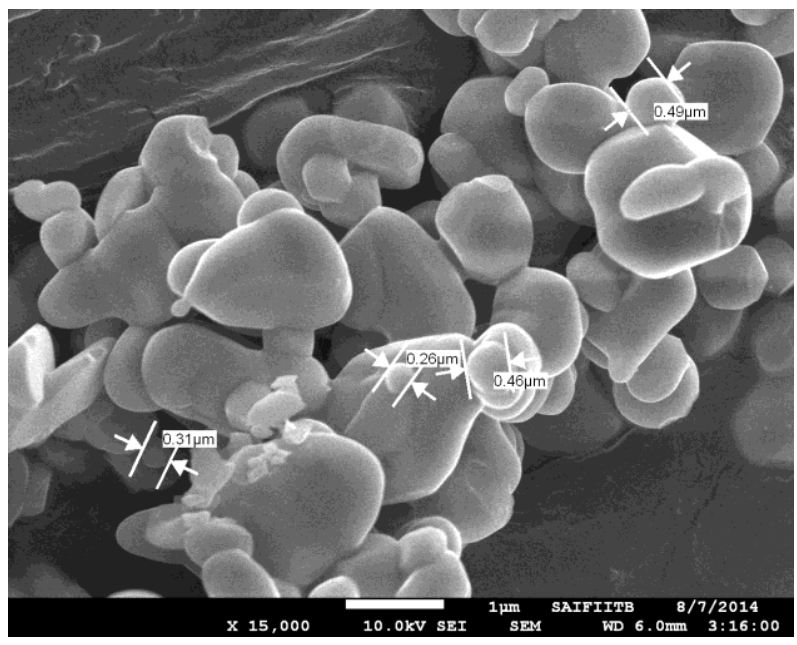

Fig 7 b:- SEM images of $\mathrm{Fe}_{2} \mathrm{O}_{3}$ obtained from $\left[\mathrm{Fe}(\mathrm{FABP})_{2} \mathrm{Cl}_{2}\right] \mathrm{Cl}$ 
The SEM micrograph of the decomposition residue of the complex $\left[\mathrm{Fe}(\mathrm{FAHP}) \mathrm{Cl}_{2}\left(\mathrm{H}_{2} \mathrm{O}\right)_{2}\right.$ ] heated at $490^{\circ} \mathrm{C}$ for 30 minutes shows that the particles are randomly arranged. The particle size is in the range of approximately $32.6 \mathrm{~nm}$ to $51.2 \mathrm{~nm}$. The aggregations of particles are also seen. Voids are present. Fig: 8a \& 8b shows the SEM images.

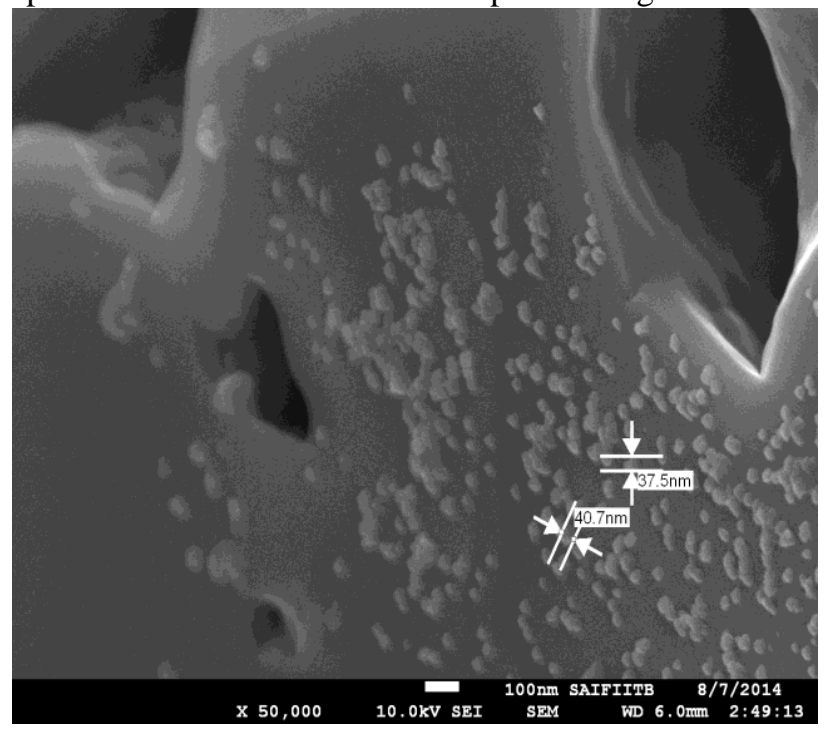

Fig 8a:-

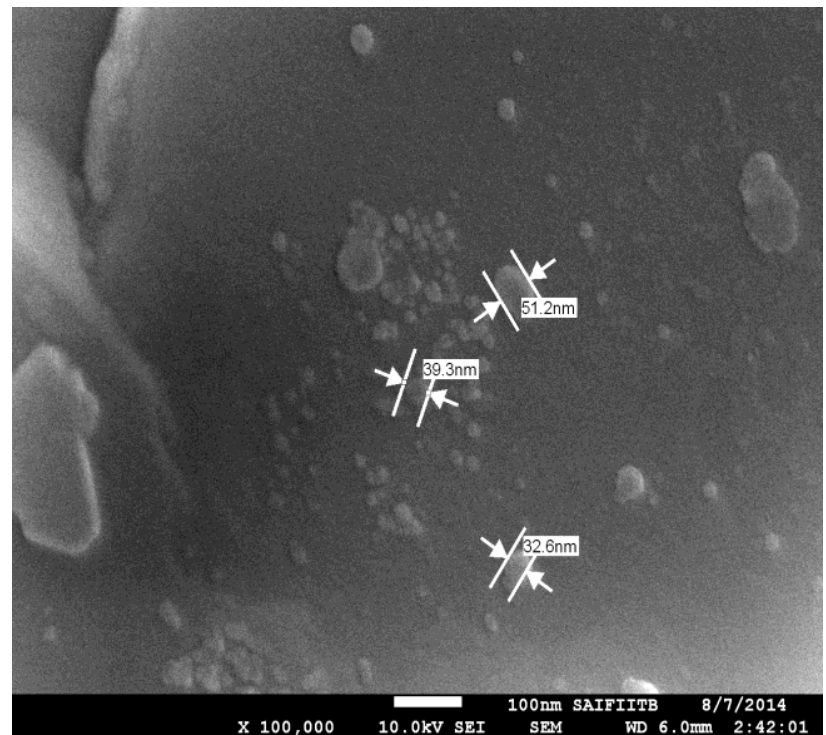

Fig8 b:- SEM images of $\mathrm{Fe}_{2} \mathrm{O}_{3}$ obtained from $\left[\mathrm{Fe}(\mathrm{FAHP}) \mathrm{Cl}_{2}\left(\mathrm{H}_{2} \mathrm{O}\right)_{2}\right]$

TEM analysis of $\mathrm{Fe}_{2} \mathrm{O}_{3}$ :-

TEM analysis is usually done to determine the size of the nano particles. The $\mathrm{Fe}_{2} \mathrm{O}_{3}$ obtained by heating the respective complexes at its pyrolytic temperature were deposited on to carbon filmed grids using a fine pipette, airdried and immediately examined by the microscope.

TEM image of $\mathrm{Fe}_{2} \mathrm{O}_{3}$ residue obtained from $\left[\mathrm{Fe}(\mathrm{RABP}) \mathrm{Cl}_{2}\left(\mathrm{H}_{2} \mathrm{O}\right)_{2}\right]$ is shown in fig: 9a, 9b \& 9c. The figure shows well defined spherical particles. The particles have narrow size distribution with a mean particle size of $51 \mathrm{~nm}-100 \mathrm{~nm}$. 


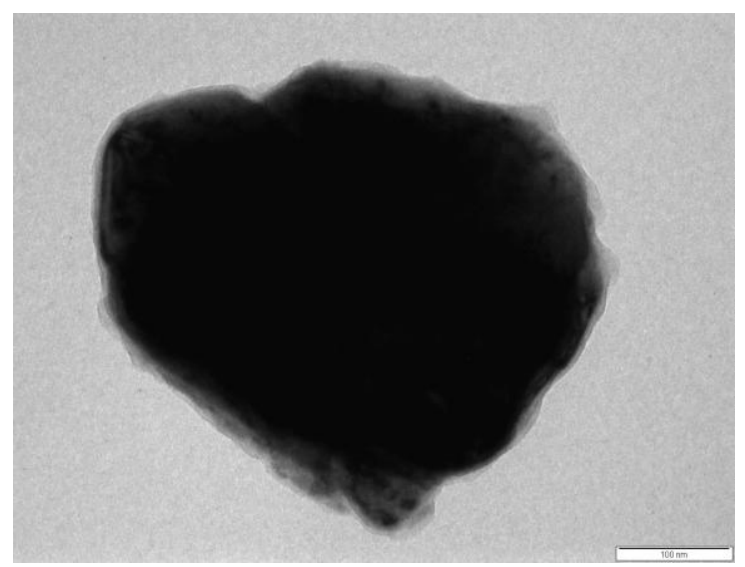

Fig 9 a:-

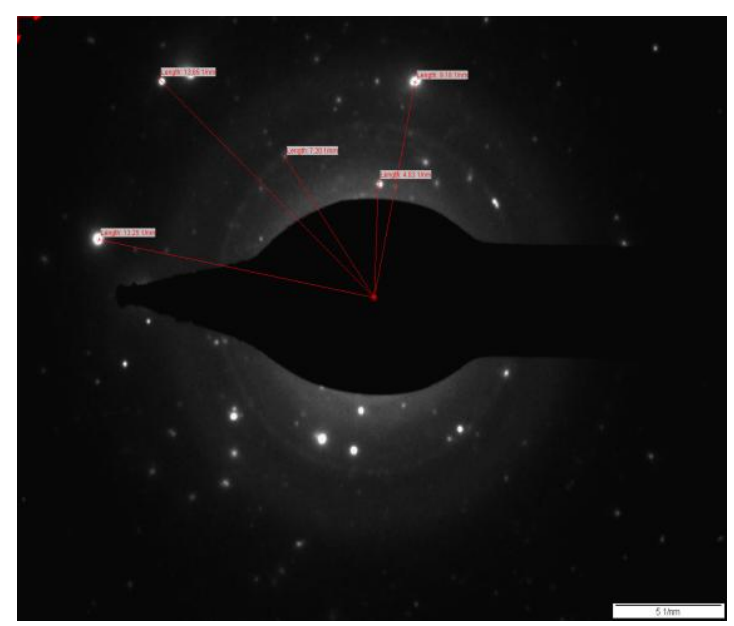

Fig 9b:-

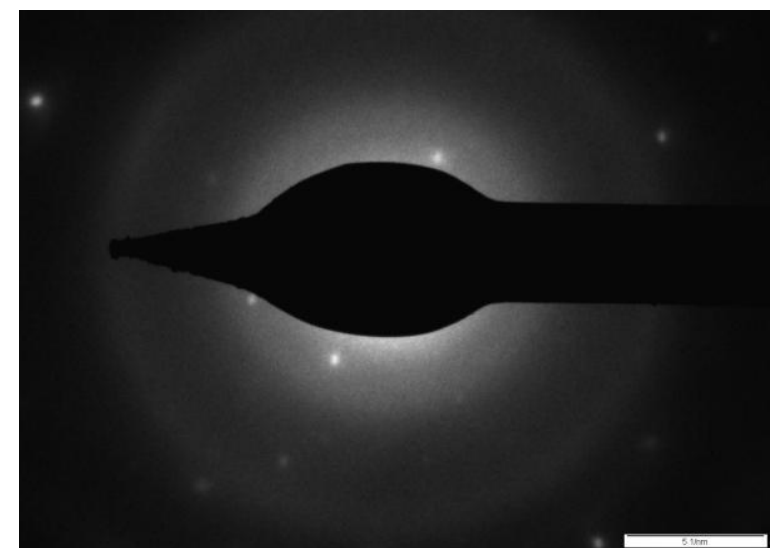

Fig 9c:- TEM images of $\mathrm{Fe}_{2} \mathrm{O}_{3}$ obtained from $\left[\mathrm{Fe}(\mathrm{RABP}) \mathrm{Cl}_{2}\left(\mathrm{H}_{2} \mathrm{O}\right)_{2}\right]$

The TEM image of $\mathrm{Fe}_{2} \mathrm{O}_{3}$ derived from $\left[\mathrm{Fe}(\mathrm{FABP})_{2} \mathrm{Cl}_{2}\right] \mathrm{Cl}$ is shown in fig:10a,10b \&10c. The figure shows well defined spherical particles with narrow sized distribution of particle with size $51 \mathrm{~nm}$. 


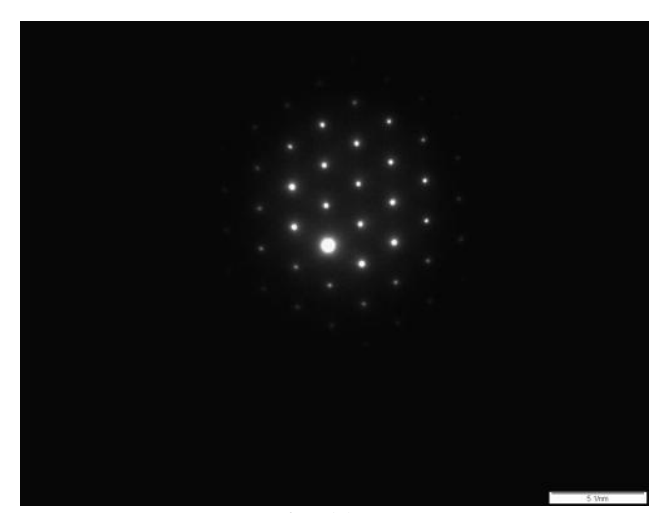

Fig 10a:-

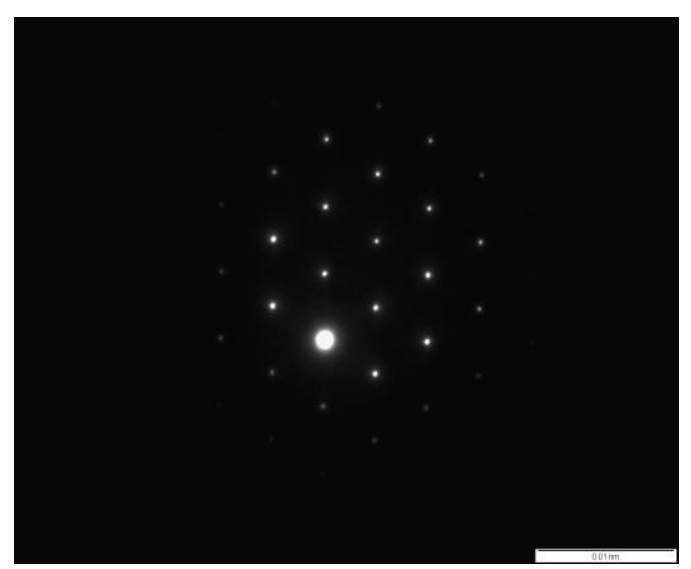

Fig 10b:-

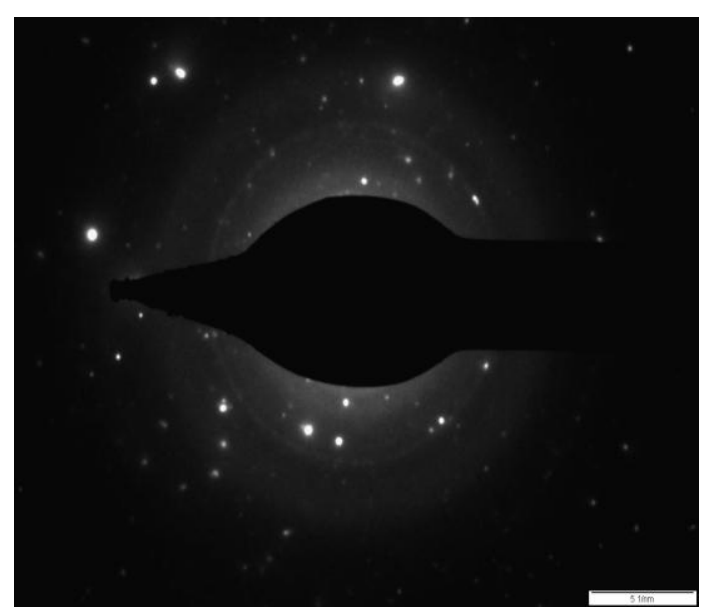

Fig 10c:- TEM images of $\mathrm{Fe}_{2} \mathrm{O}_{3}$ obtained from $\left[\mathrm{Fe}(\mathrm{FABP})_{2} \mathrm{Cl}_{2}\right] \mathrm{Cl}$

Powder x-ray diffraction analysis of the $\mathrm{Fe}(\mathrm{III})$ oxide residue:-

The XRD analysis of the residue obtained by heating the complex [Fe(RABP) $\left.\mathrm{Cl}_{2}\left(\mathrm{H}_{2} \mathrm{O}\right)_{2}\right]$ has been done and the result is compared with the JCPDS data. The XRD pattern of the $\mathrm{Fe}_{2} \mathrm{O}_{3}$ obtained is compared with the standard $\alpha$ $\mathrm{Fe}_{2} \mathrm{O}_{3}$ pattern and the planes are marked, which is shown in fig:11. The peaks observed at $\mathrm{d}$ values 3.58, 2.65, 2.48, $2.17,1.82,1.68,1.58,1.4,1.44,1.30 \AA$ matches with the peaks of rhombohedral $\alpha-\mathrm{Fe}_{2} \mathrm{O}_{3}$ (matched with JCPDS: ID 33-0664). The results of XRD shows that the complex $\left[\mathrm{Fe}(\mathrm{RABP}) \mathrm{Cl}_{2}\left(\mathrm{H}_{2} \mathrm{O}\right)_{2}\right]$ has transferred to $\alpha-\mathrm{Fe}_{2} \mathrm{O}_{3}$ during pyrolysis. A shape factor is used in X-ray diffraction and crystallography to correlate the size of sub- micrometer particle in a solid to the broadening of a peak in a diffraction pattern. The nano crystalline size can be calculated using the Scherrer's equation, 


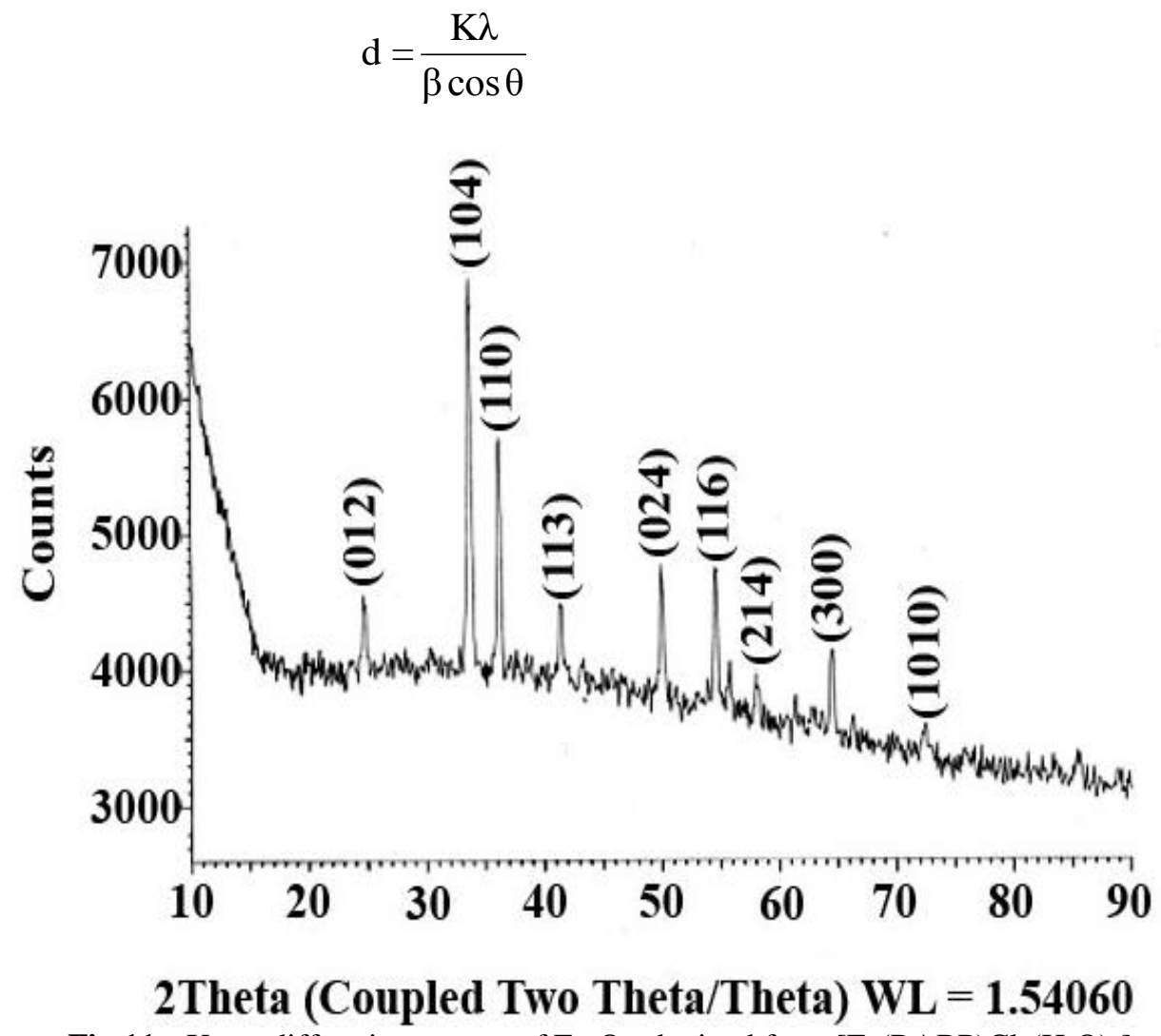

Fig 11:- X-ray diffraction pattern of $\mathrm{Fe}_{2} \mathrm{O}_{3}$ obtained from [ $\left.\mathrm{Fe}(\mathrm{RABP}) \mathrm{Cl}_{2}\left(\mathrm{H}_{2} \mathrm{O}\right)_{2}\right]$

$\mathrm{K}$ is a dimensionless shape factor $\approx 0.9, \lambda$ is the $\mathrm{X}$-ray wavelength, $\beta$ is the full width at half maximum intensity in radians (FWHM) (Lemine, O.M., 2009; Cullity, B.D., 1978). This equation is limited to nano particles. As per this equation using the data from XRD the particle size calculated was approximately $860 \mathrm{~nm}$ which approximately agrees with the data obtained from the SEM micrograph of the respective sample. The 104 peak is used for the calculation. The $\mathrm{d}$ values and the hkl planes of $\alpha-\mathrm{Fe}_{2} \mathrm{O}_{3}$ sample are listed in Table VIII(1).

Table 1:- The $\mathrm{d}$ values, relative intensities and hkl planes of the $\alpha-\mathrm{Fe}_{2} \mathrm{O}_{3}$ sample.

\begin{tabular}{|l|l|l|l|l|}
\hline Index & Angle & d Value & Rel. Intensity & hkl \\
\hline 1 & 24.7 & 3.58 & 16.1 & 012 \\
\hline 2 & 33.6 & 2.65 & 91.5 & 104 \\
\hline 3 & 36.1 & 2.48 & 57.5 & 110 \\
\hline 4 & 41.4 & 2.17 & 18.1 & 113 \\
\hline 5 & 49.9 & 1.82 & 34.6 & 024 \\
\hline 6 & 54.5 & 1.68 & 33.7 & 116 \\
\hline 7 & 58.1 & 1.58 & 7.3 & 214 \\
\hline 8 & 63.0 & 1.47 & 25.5 & 300 \\
\hline 9 & 72.5 & 1.30 & 8.2 & 1010 \\
\hline
\end{tabular}

\section{VSM measurement:-}

Magnetic characterization of nano particles was done using vibrating sample magnetometer at room temperature with a magnetic field in the range -10000 to 10000 Oe. The output from VSM measurement is a hysteresis loop (M-H loop) which shows the relationship between the induced magnetic flux density and magnetization force. The magnetization curve as a function of applied field at room temperature is shown in fig:12. From the curve we can read saturation magnetization $M_{s}$, retentivity $M_{r}$ and the coercivity $H_{c}$. For material under this study $M_{s}$ is the most concerned factor. The curve shows that the sample exhibits magnetic hysteresis with coercive force $2162.1 \mathrm{G}$ and saturated magnetic moment $22.7 \times 10^{-3} \mathrm{emu}$ and retentivity $8.0 \times 10^{-3} \mathrm{emu}$ representing ferromagnetic properties at 
room temperature. It is reported that the increase in coercivity of nano particles may be due to increase in both magnetocrystalline and shape anisotropy (Ramesh, R., et al., 2010).

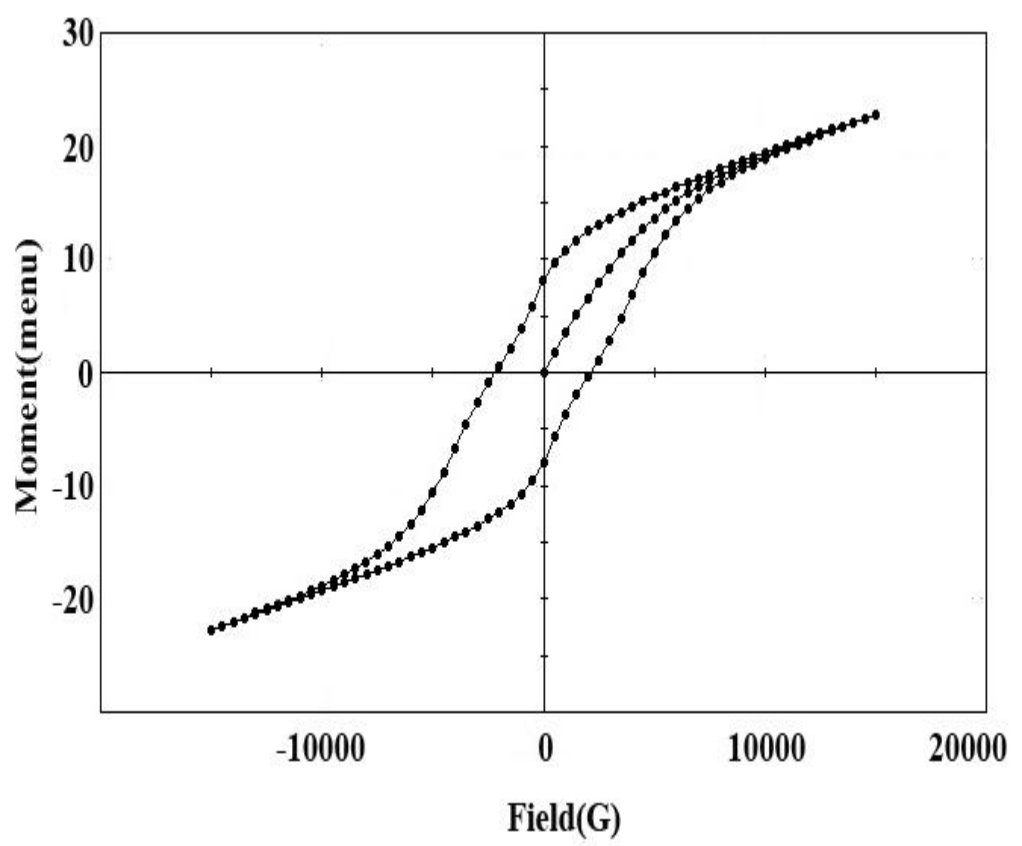

\section{Conclusion:-}

Fig 12:- VSM graph of $\mathrm{Fe}_{2} \mathrm{O}_{3}$ obtained from $\left[\mathrm{Fe}(\mathrm{FABP})_{2} \mathrm{Cl}_{2}\right] \mathrm{Cl}$

Nano crystalline $\alpha$ and $\gamma$ form of $\mathrm{Fe}_{2} \mathrm{O}_{3}$ are synthesised by thermal decomposition of few $\mathrm{Fe}(\mathrm{III})$ chelates. The percentage weights of decomposition residues match exactly with the expected weights of $\mathrm{Fe}_{2} \mathrm{O}_{3}$. From the SEM analysis of the residue obtained after thermal decomposition was found to be nano sized in all the cases. The TEM analysis also supports that the formation of nano particle of $\mathrm{Fe}_{2} \mathrm{O}_{3}$ from $\mathrm{Fe}$ (III) complexes. IR spectra of the $\mathrm{Fe}$ (III) residues again confirmed the formation of $\mathrm{Fe}_{2} \mathrm{O}_{3}$. The XRD spectra shows the peaks of $\alpha-\mathrm{Fe}_{2} \mathrm{O}_{3}$ for the residue obtained from the complex [Fe(RABP) $\left.\mathrm{Cl}_{2}\left(\mathrm{H}_{2} \mathrm{O}\right)_{2}\right]$, it matches with the JCPDS-ID. The $\gamma-\mathrm{Fe}_{2} \mathrm{O}_{3}$ nano particle obtained from the complex $\left[\mathrm{Fe}(\mathrm{FABP})_{2} \mathrm{Cl}_{2}\right] \mathrm{Cl}$ was found to exhibit ferromagnetic behaviour due to their shape anisotropy which is confirmed from the saturation magnetisation value of VSM measurement. From the results obtained on behalf of our present investigation we can conclude that nanosized $\mathrm{Fe}_{2} \mathrm{O}_{3}$ can be prepared by this controlled thermal decomposition method.

\section{Acknowledgments:-}

We express our sincere thanks to the Department of Chemistry, University College, Trivandrum for instrumental facilities under FIST-DST, SAIF IIT Bombay, SAIF IIT Chennai, STIC, Cochin University and Technology for analytical facilities.

\section{References:-}

1. Huo,L.; Li,W.; Lu, L.; Cui, H.; Xi, S.; Wang, J.; Zhao, B.; Shen, Y.; Lu, Z.,(2000) "Preparation structure and properties of three dimensional ordered $\alpha-\mathrm{Fe}_{2} \mathrm{O}_{3}$ nanoparticulate film", Chem. Mater., 12, 790.

2. Cotton, F.A.; Wilkinson, G, (1988). Advanced Inorganic Chemistry', $5^{\text {th }}$ Ed, Wiley Interscience, John Wiley and sons, New York,

3. Daou,T.J.; Greneche, J-M; Lee, S-J; Lee, S.; Lefevre, C.; sylvic B-C, Pourroy G., (2010), "Spin Canting of Maghemite studied by NMR and IN-Field Mossbauer spectrometry", J. Phys. Chem. C, 114, 2010,8794-8799.

4. Wang, J.; Meng, J., (2001), "Magnetorheological fluid devices: Properties, characteristics and applications in mechanical engineering”, Proc.Instn. Mech Engrs. 215 (Part L), 165-174.

5. Espì n, M.J.; Delgado, A.V.; Martin J.E., (2004) "Effects of electric fields and olume fraction on the rheology of hematite/ silicone oil suspensions", Rheol. Acta., 44, 873-878. 
6. Hyun Gil Cha; Chang Woo Kim; Young Hwan Kim; Mi Hyang Jung; Eun Sun Ji; Bijoy K.Das; Ju Chang Kim; Young Soo Kang; (2009), "Preparation and characterization of $\alpha-\mathrm{Fe}_{2} \mathrm{O}_{3}$ nanorod- thin film by metal- organic chemical vapour deposition". Thin Solid filims, 517, 1853-1856.

7. Murray, C.B.; Norris, D.J.; Bawendi, M.G.,(1993), "Synthesis and characterization of nearly monodisperse CdE (E = sulfur, selenium, tellurium) semiconductor nanocrystallites". J. Am. Chem. Soc. 115, 8706-8715.

8. Langevin, D., (1992) "Micelles and Microemulsions". Annu Rev Phys Chem 43, 341-369.

9. Daou, T.J.; Pourroy, G.; Begin-Colin.; S, Greneche, J.M.; Ulhaq-Bouillet, C.; et al., (2006) "Hydrothermal Synthesis of Monodisperse Magnetite Nanoparticles". Chem Mater 18, 4399-4404.

10. Sohn, B.H.,Cohen, R.E., (1997), "Processible optically transparent block-copolymer films containing superparamagnetic iron- oxide nano clusters", Chem. Mater. 9, 264-269.

11. Benyettou, F.; Hardouin, J.; Marc Lecouvey; Jouni, H.; Motte, L., (2012), "PEGylated Versus NonPEGylated $\mathrm{Fe}_{2} \mathrm{O}_{3} @$ Alendronate Nanoparticles". J Bioanal Biomed 4, 39-45.

12. Taranta. M.; Naldi, I.; Grimaldi, S.; Salvini, L.; Claudio, P.P.; et al.,(2011), "Magnetically Driven Bioreactors as new Tools in Drug Delivery". J Bioanal Biomed, S5, 002.

13. Anand kumar Sharma; (1986) "Review on Thermal behavior of metal dithiocarbamates", Thermochim. Acta., 104, 339-372.

14. Lanje war, R.B.; Kawata,S.; Nawa,T.; Kitagawa, S.; Garg, A.N.; Katada, M.; (1996), "Mössbauer spectroscopic and thermal decomposition studies of alkylamine and nitrogen heterocyclic substituted pentacyanoferrate (II) complexes", Thermochim.Acta., 287, 111-129.

15. Sonal singhal; Garg, A.N.; Chandra, K., (2007)," Synthesis of tris (N,N-dialkyl dithiocarbamato) iron (III) complexes and their thermal decomposition studies by various techniques", J. Alloys Compd.,428, 72-78.

16. Mini, S.; Meena, S.S.; Pramod Bhatt, Sadasivan, V.;Vidya, V.G., (2013) "Synthesis and characterization of Fe(III) complex of an azo dye derived from (2-amino-5-chlorophenyl) phenyl methanone", AIP Conf.Proc., 1536, 1011-1012.

17. Mini, S.; Sadasivan, V.; Meena, S.S. and Pramod Bhatt, (2014) "Spectroscopic studies on two mono nuclear iron (III) complexes derived from a Schiff base and an azodye", AIP Conf. Proc., 1620, 322-326.

18. Mini, S.; Sadasivan, V.; Meena, S.S. and Pramod Bhatt., (2015), "Synthesis and Spectral Studies of Metal Complexes of a Schiff Base Derived from (2-amino-5-chlorophenyl) Phenyl Methanone", Spectro. Chim.Acta. , vol (15), 598-604.

19. Stuart, B.H.,(2004), 'Infrared Spectroscopy:Fundamentals and Applications', Wiley, England.

20. Battisha, J.k.; Afify, H.H., Ibrahim, M., (2006), "Synthesis of $\mathrm{Fe}_{2} \mathrm{O}_{3}$ concentrations and sintering temperature on FTIR and Magnetic susceptibility measured from 4 to 300k of monolith silica gel prepared by sol-gel technique", J.Magn. Magn. Mater., 306, 2006, 211-215.

21. Kim, I. T.; Nunnery, G. A.; Jacob, K.; Schwartz, J.; Liu, X.; Tannenbaum, R.,(2010), "Synthesis, characterization and alignment of Mgnetic carbon nanotubes tethered with maghemite carbon nanoparticles", $J$. Phy. Chem., 114, 6944-6951.

22. Zhao, X.; Lee, P.P.F.; Yan, Y. K.; Chu, C.K.,(2007), "Synthesis, crystal structures and cytotoxicities of some transition metal complexes with N-[2-\{(pyridin-2-ylmethylidene) amino\}ethyl $]$ acetamide", J. Inor. Biochem., 101, 321-328.

23. Ning Du; Yanfang Xu; Hui zhang; chuanxin Zhai; Deren yang,(2010), "Selctive synthesis of $\mathrm{Fe}_{2} \mathrm{O}_{3}$ and $\mathrm{Fe}_{3} \mathrm{O}_{4}$ nanowires via a single precursor: A general Method for metal Oxide Nanowires," Nano Scale.Res. Lett., 5, 1295-1300.

24. Lemine,O.M., (2009), "Microstructural characterization of $\alpha-\mathrm{Fe}_{2} \mathrm{O}_{3}$ nanoparticle using XRD, line profiles analysis, Fe-SEM and FT-IR, Super lattice". Microst., 45, 576-582.

25. Cullity, B. D., (1978).,'Elements of X-ray diffraction, Addison Wesley Publishing Co. Inc., New York, .

26. Ramesh, R.; Ashok, K.; Bhalero, G.M., Ponnusamy, S.; Muthamizhchelvan, (2010), "Synthesis and properties of $\alpha-\mathrm{Fe}_{2} \mathrm{O}_{3}$ nano rods". Cryst. Res. Technol., 45, 965-968 